\title{
Seasonal variations of phosphate availability in the SW Pacific Ocean near New Caledonia
}

\author{
Nathalie Van Den Broeck ${ }^{1}$, Thierry Moutin ${ }^{1, *}$, Martine Rodier ${ }^{2}$, \\ Aubert Le Bouteiller ${ }^{2}$
}

${ }^{1}$ Laboratoire d'Océanographie et de Biogéochimie (UMR 6535), Centre d'Océanologie de Marseille, Campus de Luminy, 13288 Marseille Cedex 09, France

${ }^{2}$ Institut de Recherche pour le Développement, BP A5, 98848 Nouméa, Nouvelle Calédonie, France

\begin{abstract}
Seasonal availability of phosphate was assessed by the examination of P pools and turnover times of orthophosphate on 6 cruises between October 2001 and August 2002 in the upper water column ( 0 to $120 \mathrm{~m}$ ) of the oligotrophic SW Pacific Ocean near New Caledonia $\left(21^{\circ} 30^{\prime} \mathrm{S} ; 167^{\circ} \mathrm{E}\right)$. While the soluble reactive phosphate (SRP) concentration was below the analytical chemical detection limit $(30 \mathrm{nM})$ in summer and fall, it reached detectable values in winter and spring. The annual mean depth-integrated (0 to $100 \mathrm{~m}$ ) SRP pool was $6.8 \mathrm{mmol} \mathrm{m}^{-2}(\mathrm{SD}=3.9, \mathrm{n}=6)$. Particulate phosphate (PP) and soluble non-reactive phosphate (SNP) pools were, respectively, $1.7(\mathrm{SD}=0.3, \mathrm{n}=6$ ) and $23.0 \mathrm{mmol} \mathrm{m}^{-2}(\mathrm{SD}=4.8, \mathrm{n}=6)$. A strong seasonal variation of turnover times $(T)$ of orthophosphate was observed ( 0.17 to $19 \mathrm{~d}$ ) in the upper water column, with shorter values in summer and fall. Indirectly estimated orthophosphate concentration $\left(\left[\mathrm{PO}_{4}\right]\right)$, based on turnover time measurements, ranged from 56 to $118 \mathrm{nM}$ in winter to 0.3 to $0.8 \mathrm{nM}$ in fall. A seasonal P sufficiency in spring and winter $\left.T>100 \mathrm{~h}_{i}\left[\mathrm{PO}_{4}\right]>20 \mathrm{nM}\right)$ and a strong deficiency in summer $\left(T<15 \mathrm{~h}_{i}\left[\mathrm{PO}_{4}\right]<2 \mathrm{nM}\right)$ and the beginning of fall $\left(T<5 \mathrm{~h}_{;}\left[\mathrm{PO}_{4}\right]<1 \mathrm{nM}\right)$ occurred. This P deficiency was larger than at the ALOHA station in the North Pacific Ocean. Primary production and phosphate availability followed the same seasonal pattern. In this iron-rich area known to sustain high $\mathrm{N}_{2}$ fixation rates, phosphate may appear as a key factor controlling carbon production.
\end{abstract}

KEY WORDS: Phosphate $\cdot$ Turnover $\cdot$ Pacific Ocean $\cdot$ Primary production Resale or republication not permitted without written consent of the publisher

\section{INTRODUCTION}

In oceanic waters, nitrogen has traditionally been viewed as the nutrient-limiting productivity (Eppley et al. 1973, Codispoti 1989), and the biological pump of carbon (Bishop 1989). Nitrate is the main external source of inorganic nitrogen, which supports primary production, but recently $\mathrm{N}_{2}$ has been considered as a non-negligible source of new nitrogen (Capone 2001). $\mathrm{N}_{2}$ fixation has been viewed as a globally important process in the $\mathrm{N}$ cycle and in global oceanic productivity (Carpenter \& Romans 1991, Capone 2001); it has been estimated that it could contribute up to half of the new production in the subtropical North Pacific Ocean (Karl et al. 1997). This input of new $\mathrm{N}$ by $\mathrm{N}_{2}$ fixation into the surface ocean could potentially relieve the ecosystem of N limitation (Tyrell 1999). Understanding the controls on nitrogen fixation will further our ability to estimate the capacity of specific oceanic ecosystems to produce and export carbon (Falkowski 1997, Capone 2001).

Diazotrophs are not limited by the availability of nitrogen. Environmental factors, such as temperature or turbulence, are likely to influence $\mathrm{N}_{2}$ fixation. The other most crucial environmental control on $\mathrm{N}_{2}$ fixation is the bioavailability of the other nutrients which can constrain the extent of nitrogen fixation in a system, such as phosphate (Karl et al. 1997, 2002, Sañudo-Wilhelmy et al. 2001), or trace metals such as iron (Falkowski 1997, Kutska et al. 2002, Fu \& Bell 2003) and molybdenum (Karl et al. 2002), which are required for the activity of nitrogenase. Phosphate availability is 
probably the second controlling factor for new carbon production. Indeed, biomass P-requirements are high in comparison with in situ concentrations, which are close to or below the standard analytical detection limit in many oceanic areas (Wu et al. 2000, Karl et al. 2001a, Moutin et al. 2002). Furthermore, over the last decade Karl et al. (1997) have observed an increase in diazotrophic populations at the ALOHA (A Long-term Oligotrophic Habitat Assessment) station located in the Subtropical North Pacific Gyre, along with a decrease in soluble reactive phosphate and an apparent shift from nitrogen limitation to phosphate limitation.

We studied phosphate availability for phytoplankton near New Caledonia from October 2001 to August 2002 in an area where blooms of the $\mathrm{N}_{2}$-fixing cyanobacterium Trichodesmium are frequently observed (Dupouy 1992, Dupouy et al. 2000) and where the variability of the nutrient environment and the associated biological responses are still insufficiently described in the literature (Radenac \& Rodier 1996). Particulate phosphate (PP), soluble non-reactive phosphate (SNP) and soluble reactive phosphate (SRP) were measured in the upper water column. Additionally, orthophosphate turnover times were measured using ${ }^{33} \mathrm{P}-\mathrm{PO}_{4}$, which allowed the indirect estimation of orthophosphate concentrations. We then go on to discuss the availability of phosphate for planktonic production. Finally, these results, obtained in the relatively unknown SW Pacific Ocean, are compared with data from the ALOHA station.

\section{MATERIALS AND METHODS}

Station location and cruise chronology. This paper focuses on one station, named 'Chenal des Loyauté' $\left(21^{\circ} 30^{\prime} \mathrm{S} ; 167^{\circ} \mathrm{E}\right)$, located in the middle of the Loyalty Channel, between the Loyalty Islands and the main island of New Caledonia (Fig. 1). It is in the sub-tropics, southwest of the South Pacific convergence zone, in the SE trade wind belt, a region directly affected by the El Niño Southern Oscillation (Delcroix \& Lenormand 1997). The station Chenal des Loyauté is located in deep water $(2200 \mathrm{~m})$, upwind and at a sufficient distance from land (ca. 50 miles), and is therefore free from coastal ocean dynamics and biogeochemical influences. Six cruises were carried out aboard RV 'Alis', from October 2001 to August 2002 as part of the DIAPAZON program (Diazotrophic Pacific Zone). Details of cruise dates are given in Table 1.

Sample collection and hydrological characteristics. Seawater samples were collected at 8 to 10 predetermined depths in 81 Niskin bottles attached to a rosette CTD system, before dawn. Subsamples were collected directly, without pre filtration, into clean and samplerinsed polycarbonate bottles. High vertical resolution environmental data were achieved using a CTD (Seabird) profiling system, between 0 and $200 \mathrm{~m}$, measuring external temperature, conductivity, fluorescence and depth. From the temperature and salinity profiles, the vertical density distribution was determined. Mixed layer depth was estimated as the depth at which the first difference per $50 \mathrm{~cm}$ between densi-

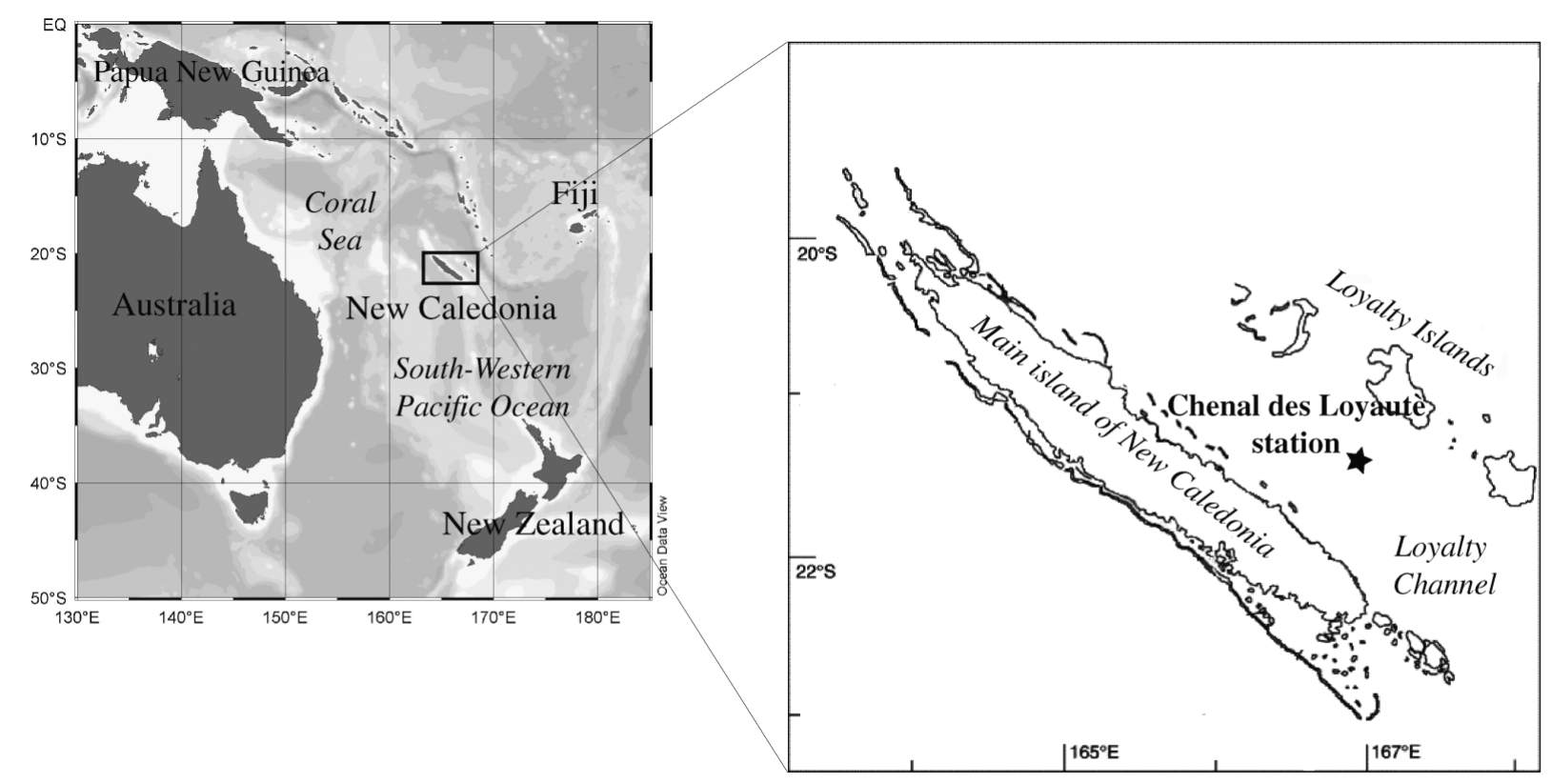

Fig. 1. Study area in the SW Pacific Ocean, showing location of Chenal des Loyauté station in the Loyalty Channel 
Table 1. DIAPAZON program chronology. Mixed-layer depth (MLD) and characteristics of phosphacline-depths $\left(D_{\mathrm{PO} 4}\right)$ and slopes $\left(S_{\mathrm{PO} 4}\right)$ where the soluble reactive phosphorus (SRP) concentration reaches zero-at Chenal des Loyauté station. $\mathrm{n}$ is the number of sample depths allowing the calculation of $\mathrm{D}_{\mathrm{PO} 4}$ and $\mathrm{S}_{\mathrm{PO} 4} \cdot-$ : no data available

\begin{tabular}{|c|c|c|c|c|c|c|c|}
\hline \multirow[b]{3}{*}{ Spring } & \multirow{3}{*}{$\begin{array}{l}\text { Cruise } \\
\text { Diapalis } 1\end{array}$} & \multirow{3}{*}{$\begin{array}{c}\text { Date } \\
\text { d/mo/yr }\end{array}$} & \multirow{3}{*}{$\begin{array}{c}\text { MLD } \\
(\mathrm{m}) \\
12.5\end{array}$} & \multicolumn{4}{|c|}{ - Phosphacline _- } \\
\hline & & & & \multicolumn{3}{|c|}{ 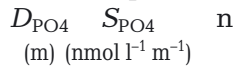 } & \multirow{2}{*}{$\begin{array}{c}\mathrm{r}^{2} \\
0.97\end{array}$} \\
\hline & & & & 44 & 0.15 & 3 & \\
\hline \multirow[t]{2}{*}{ Summer } & Diapalis 2 & $10 / 12 / 01-22 / 12 / 01$ & 46 & 70 & 0.18 & 3 & 0.99 \\
\hline & Diapalis 3 & $15 / 01 / 02-22 / 01 / 02$ & 27.5 & 42 & 0.40 & 4 & 0.98 \\
\hline \multirow[t]{2}{*}{ Fall } & Diapalis 4 & 02/04/02-09/04/02 & 4 & 48 & 0.31 & 5 & 0.93 \\
\hline & Diapalis 5 & $22 / 05 / 02-28 / 05 / 02$ & 18.5 & 50 & 0.22 & 4 & 0.96 \\
\hline Winter & Diapalis 6 & 05/08/02-11/08/02 & 71.5 & 97 & 0.06 & 2 & - \\
\hline
\end{tabular}

ties in 2 consecutive data was $>0.001 \mathrm{~kg} \mathrm{~m}^{-3}$. As SRP concentration vs depth at the beginning of the phosphacline may be linearized, phosphacline was characterized by its slope $(S)$ and the depth $(D)$ where SRP will be zero $\left(D_{0}\right)$ according to Moutin \& Raimbault (2002). This method was considered to be more precise for a discrete sampling vs depth than the determination of the depth where nutrients become clearly measurable.

Analytical methods. $P$ pool: The SRP pool was estimated immediately on board using the molybdenum blue reaction (Murphy \& Riley 1962), on $50 \mathrm{ml}$ samples, using a $10 \mathrm{~cm}$ length-cuve in a spectrophotometer Cecil CE 1011, at $885 \mathrm{~nm}$, following $30 \mathrm{~min}$ reaction. Concentration was expressed in nM. According to Benitez-Nelson (2000), the lower limit of detection for SRP was $30 \mathrm{nM}$.

Particulate phosphate (PP) was determined by filtration of 1 l samples through polycarbonate filters $(0.2 \mu \mathrm{m} ; 4 \mathrm{~mm})$. Particulate phosphate was measured by standard SRP analysis, at $880 \mathrm{~nm}$, following hightemperature persulfate wet-oxidation at $120^{\circ} \mathrm{C}$ and 1 bar (Valderrama 1981, Pujo-Pay \& Raimbault 1994), which converted all inorganic and organic non-reactive P compounds to SRP.

Total phosphate (TP) was estimated from $40 \mathrm{ml}$ duplicate samples of seawater, using the same hightemperature persulfate wet-oxidation pre-treatment as for PP. SRP was then analysed classically, as previously described. The measurement of SNP in seawater requires simultaneous measurements of SRP and TP. SNP was assumed to be equal to ([TP] - [SRP] - [PP]). Precision and accuracy of SNP estimates decreased with increasing depth, when SRP concentrations became the dominant components of the total dissolved nutrient pools.

Turnover times of orthophosphate: The orthophosphate turnover time $(T)$ corresponds to the ratio of concentration and uptake of orthophosphate. According to
Thingstad et al. (1993), turnover time was assumed to be related to the fraction of radioactivity absorbed following the theoretical expression:

$$
r(t)=\left(1-\mathrm{e}^{-t / T}\right)
$$

where $r$ is the fraction of added radioactivity absorbed, and $t$ is the incubation time. The equation was rearranged to allow a direct calculation of turnover time:

$$
T=-t / \ln \left(1-R_{(t)}\right)
$$

with $R_{(t)}=\left(R_{\mathrm{f}}-R_{\mathrm{b}}\right) / R_{\mathrm{t}}$, where $R_{\mathrm{f}}$ is the radioactivity on the filter, $R_{\mathrm{b}}$ is the radioactivity of the blank, and $R_{\mathrm{t}}$ is the total tracer added. This calculation of turnover time of orthophosphate assumed that the regeneration rate equals the orthophosphate uptake rate in samples. It did not require the knowledge of the ambient orthophosphate concentration. The turnover time is also the time it would take for all the ambient phosphate to be taken up, assuming no additional input (Ammerman et al. 2003).

Turnover time of orthophosphate was determined using ${ }^{33} \mathrm{P}$ tracer (orthophosphate in dilute hydrochloric acid; Amersham BF 1003; specific activity > $3000 \mathrm{Ci}$ $\mathrm{mmol}^{-1}$ ). The working solution of ${ }^{33} \mathrm{P}$-orthophosphate was prepared by dilution of the tracer in Milli-Q water filtered on pre-washed $0.2 \mu \mathrm{m}$ filters immediately before use. We dispensed $300 \mathrm{ml}$ of seawater into acidwashed, Milli-Q and sample-rinsed polycarbonate bottles, and incubated with $25 \mu \mathrm{Ci}$ carrier-free ${ }^{33} \mathrm{PO}_{4}$ (of working solution to give a total activity of $1.8 \times 10^{5}$ counts per minute $[\mathrm{cpm}] \mathrm{ml}^{-1}$ ). Therefore, less than $0.03 \mathrm{nM}$ of $\mathrm{P}$ were added to each sample. The bottles were then placed in an on-deck incubator maintained at constant temperature using a continuous circulation of surface seawater, at $90 \%$ incident light. Light intensity did not appear to affect the $\mathrm{PO}_{4}$ uptake rate (Perry 1976, Herbland 1984, Moutin et al. 2002). The same protocol was used for duplicate $300 \mathrm{ml}$ samples where $300 \mu \mathrm{HgCl}_{2}\left(20 \mathrm{~g} \mathrm{l}^{-1}\right)$ had been added in order to control for non-biological uptake. Incubations were stopped by the addition of $1 \mathrm{ml}$ of non-radioactive $\mathrm{KH}_{2} \mathrm{PO}_{4}(10 \mathrm{mM})$. Optimal incubation time was determined from a prior time-series experiment. Sample counts should be at least 10 times greater than the blanks. Less than $25 \%$ of the radioactivity in the samples should be consumed, and finally, incubation should not exceed several hours in order to minimize the increase in bacterial production caused by confinement. Optimal incubation times were chosen between 1 to $7 \mathrm{~h}$ among cruises. Orthophosphate assimilation was measured in $50 \mathrm{ml}$ subsamples from each bottle (con- 
ducted in duplicate or triplicate). Filtrations were performed on $25 \mathrm{~mm}$ polycarbonates filters $(0.2 \mu \mathrm{m})$, placed on phosphate-saturated support GF/F filters, using a low-pressure suction $<0.2$ bars. Filters were not washed with filtered seawater at the end of the filtration, but suction was briefly increased to 0.6 bars, to remove non-cellular radioactivity from the filter. Filters were then stored in scintillation vials until counted. In the laboratory, $4 \mathrm{ml}$ of scintillation liquid (Ultima gold MV, Packard) were added and the radioactivity of the filters was measured using a scintillation counter TriCarb 2100 TR (Packard). Initially added radioactivity was measured on 5 replicates of $20 \mu$ of working solution in parallel of each experiment to verify the amount of ${ }^{33} \mathrm{P}$ added to each sample.

Calculation of the 'indirectly estimated orthophosphate concentration', [PO $\mathbf{P O}_{4}$ : According to Moutin et al. (2002), $\left[\mathrm{PO}_{4}\right]$ was estimated using turnover time of orthophosphate $\mathrm{T}$, carbon primary production $\left(\mathrm{PP}_{\mathrm{r}}\right)$ and carbon bacterial production $\left(\mathrm{BP}_{\mathrm{r}}\right)$ with the formula:

$$
\left[\mathrm{PO}_{4}\right]=T \times\left(\mathrm{PP}_{\mathrm{r}} / 106+\mathrm{BP}_{\mathrm{r}} / 50\right)
$$

where $\left[\mathrm{PO}_{4}\right]$ was expressed in $\mathrm{nM}, T$ in $\mathrm{d}_{1} \mathrm{PP}_{\mathrm{r}}$ and $\mathrm{BP}$ in $\mathrm{nM} \mathrm{d}^{-1}$ and taking a C:P ratio of 106 and 50 respectively. This calculation gave an estimate of the instantaneous 'real' orthophosphate concentrations available to microorganisms in oligotrophic waters. It provided to estimate subnanomolar concentrations $(<2 \mathrm{pM})$, but with an uncertainty of a factor of ca. 2 in the results (see 'Discussion'). In order to realize this calculation, primary production and bacterial production were also measured, in parallel to orthophosphate turnover times.

Primary production was measured using ${ }^{14} \mathrm{C}$ method. Duplicate $260 \mathrm{ml}$ samples were incubated in situ with 5 or $10 \mu \mathrm{Ci}$ of ${ }^{14} \mathrm{C}$, for 6,12 or $24 \mathrm{~h}(12 \mathrm{~h}$ in situ and $12 \mathrm{~h}$ in on-deck incubators). Following incubation, samples were collected onto $25 \mathrm{~mm} \mathrm{GF/F} \mathrm{filters.} \mathrm{The} \mathrm{vials} \mathrm{were}$ dried for 2 to $6 \mathrm{~h}$ at $50^{\circ} \mathrm{C}$ following the addition of $100 \mu \mathrm{l}$ of $\mathrm{HCl} 0.5 \mathrm{~N}$ before adding $4 \mathrm{ml}$ of Ultima gold MV (Packard). Radioactivity was then analyzed using a TriCarb 2100 TR (Packard) scintillation counter in the laboratory. Primary production rates were converted to nM $\mathrm{d}^{-1}$ using conversion factors (Moutin et al. 1999).

Bacterial production was studied from fall to winter for 6 predefined depths. It was estimated using ${ }^{3} \mathrm{H}$ methyl-thymidine (Fuhrman \& Azam 1982). Duplicates of $30 \mathrm{ml}$ were incubated with $15 \mathrm{nM}$ of ${ }^{3} \mathrm{H}$-methylthymidine (Amersham). Three samples were killed with formalin $2 \%$ prior to isotope addition for experimental controls. Samples were incubated in the same incubator as for turnover times of phosphate measurements. The incubations were stopped after $1.5 \mathrm{~h}$ using formalin ( $2 \%$ final concentration) and unlabeled thymidine. The samples were then filtered through
$0.2 \mu \mathrm{m}$ polycarbonate filters (Millipore) placed on thymidine-saturated GF/F filters, extracted and rinsed 3 times with $5 \%$ trichloroacetic acid (TCA). Four ml of Ultima gold MV (Packard) were added and radioactivity was analyzed by a Tri-Carb 2100 TR (Packard) scintillation counter in the laboratory. Conversion factors were used to obtain bacterial carbon production in nM $\mathrm{d}^{-1}$ (Fuhrman \& Azam 1982, Fukuda et al. 1998).

The detection limit of $\left[\mathrm{PO}_{4}\right]$ was 2 pM. It was determined using the lowest turnover time of phosphate and the lowest primary and bacterial productions, which can be significantly measured $\left(T=0.25 \mathrm{~h}, \mathrm{PP}_{\mathrm{r}}=15 \mathrm{nM}\right.$ $\mathrm{d}^{-1}$ and $\left.\mathrm{BP}_{\mathrm{r}}=2 \mathrm{nM} \mathrm{d}^{-1}\right)$.

\section{RESULTS}

\section{Hydrological characteristics}

Salinity in the first $200 \mathrm{~m}$ of the water column ranged from 35 to 35.7 throughout the year (Fig. 2a), except for the occasional influx of low-salinity waters (from 34.4 to 35) down to a depth of $50 \mathrm{~m}$ in April, related to the high precipitations which occurred over this period. Temperature of the upper water column (0 to $200 \mathrm{~m}$ ) ranged

(a) $\mathrm{S}$

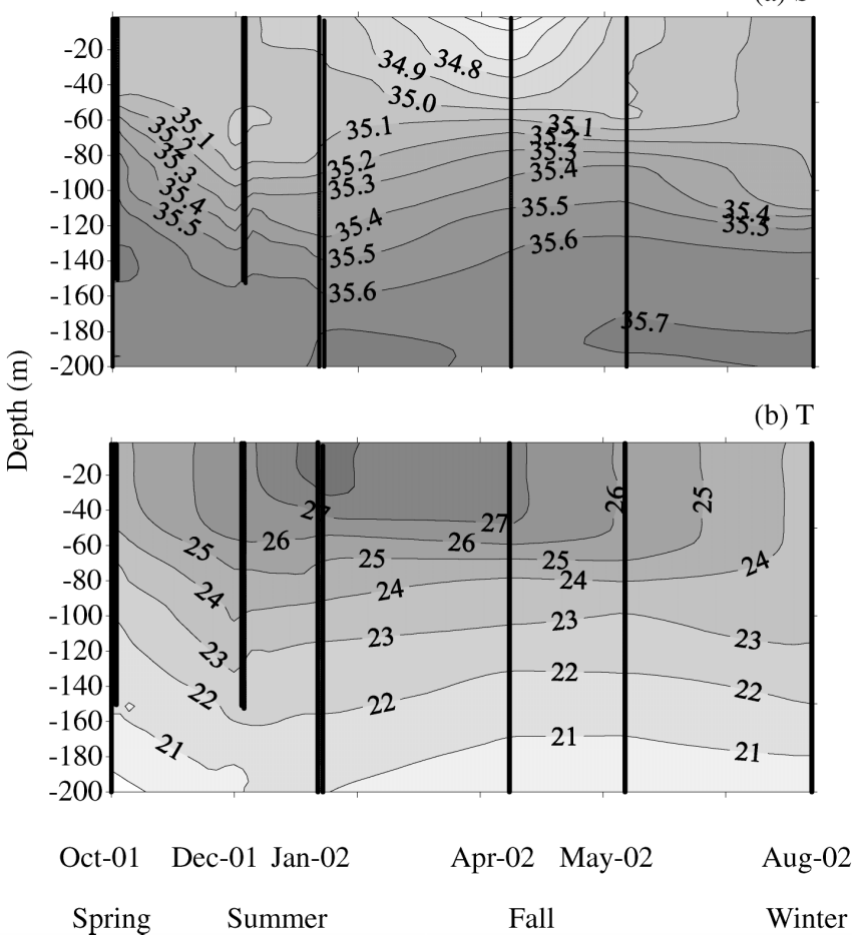

Fig. 2. Hydrological characteristics at Chenal des Loyauté station from October 2001 to August 2002, in the 0 to $200 \mathrm{~m}$ water column. Isopleths diagram for (a) salinity ( $S_{\text {; }} \mathrm{psu}$ ), and (b) temperature $\left(\mathrm{T}_{i}{ }^{\circ} \mathrm{C}\right)$. Black (overlapping) circles indicate sampling points 
from $20^{\circ} \mathrm{C}$ around $200 \mathrm{~m}$ throughout the year, to $28^{\circ} \mathrm{C}$ in the surface waters during summer (Fig. 2b). The maximum temperature occurred at the beginning of the year in January, and the minimum in August, with temperatures $<24^{\circ} \mathrm{C}$. The same seasonal trend was already described in this area by Hénin et al. (1984).

\section{P pool}

SRP concentrations in the upper water column were near or below the detection limit of the traditional analytical technique throughout the year and especially in summer and fall (Fig. 3a). Concentrations were low $(<30 \mathrm{nM})$ in near-surface waters, and increased with

(a) SRP

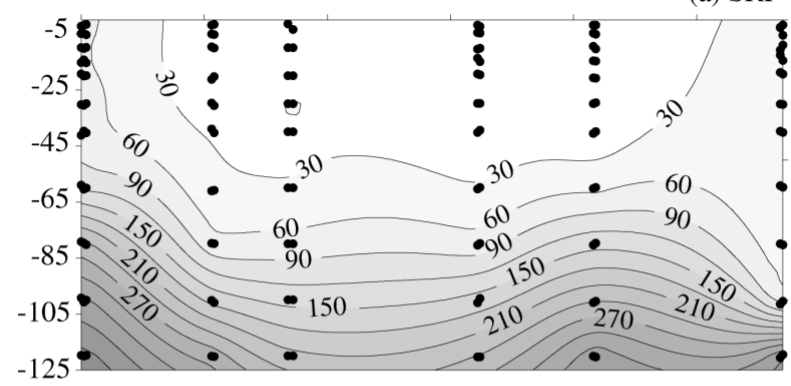

(b) SNP

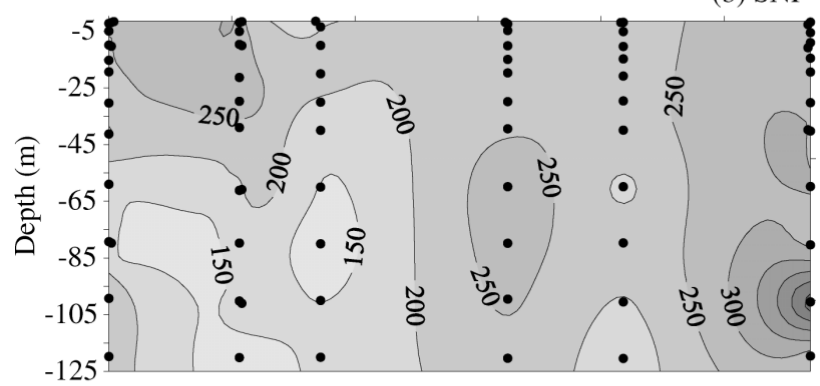

(c) PP

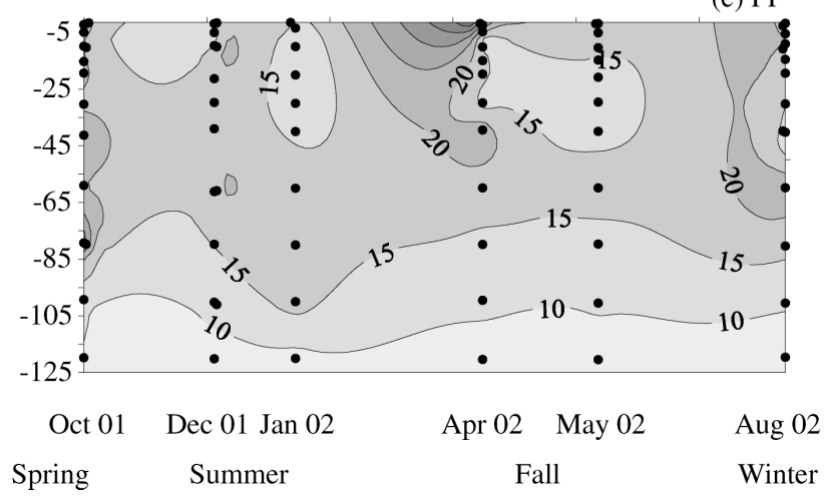

Fig. 3. Concentrations (nM) of (a) soluble reactive phosphate (SRP), (b) soluble non-reactive phosphate (SNP) and (c) particulate phosphate (PP), in the 0 to $100 \mathrm{~m}$ water column, at Chenal des Loyauté station from October 2001 to August 2002 depth to reach more than $250 \mathrm{nM}$ at $120 \mathrm{~m}$, with a maximum of $411 \mathrm{nM}$ in spring. Throughout the year, SRP concentrations were $<100 \mathrm{nM}$ in the first $60 \mathrm{~m}$ of the water column. The mean concentration of SRP in the mixed layer was $63 \mathrm{nM}(\mathrm{SD}=13 ; \mathrm{n}=3)$ in spring, decreasing to values $<30 \mathrm{nM}$ in summer and fall, and increasing in winter to ca. $44 \mathrm{nM}$ (Table 2). Depth of the phosphacline $\left(D_{0}\right)$ varied from $42 \mathrm{~m}$ at the end of summer to $97 \mathrm{~m}$ in winter (Table 1). Slopes were minimum in winter $\left(0.06 \mathrm{nM} \mathrm{m}^{-1}\right)$ and maximum in summer $\left(0.40 \mathrm{nM} \mathrm{m}^{-1}\right)$. Annual mean depth-integrated SRP (0 to $100 \mathrm{~m})$ was $6.8 \mathrm{mmol} \mathrm{m}^{-2}(\mathrm{SD}=3.9 ; \mathrm{n}=6$ ) (Table 3 ). The spring value was the highest of the year, with 14.5 $\mathrm{mmol} \mathrm{m}{ }^{-2}$. Then, this stock decreased to a minimum of $4.3 \mathrm{mmol} \mathrm{m}^{-2}$ in fall (April). Stocks of SRP were calculated considering a SRP concentration equal to 0 when it was under the detection limit. When considering a concentration equal to $30 \mathrm{nM}$ instead of 0 , differences in the stocks results reached $18 \%$ at a maximum value.

Surface SNP represented the dominant component of the P pool, accounting for 80 to $90 \%$ of the total dissolved pools (Fig. 3b). No large seasonal variability on mean SNP concentrations in the mixed layer was observed (Table 2); they varied between $211 \mathrm{nM}(\mathrm{SD}=$ $16 ; \mathrm{n}=4)$ in January to $281 \mathrm{nM}(\mathrm{SD}=15 ; \mathrm{n}=8)$ in August. Annual depth integrated SNP mean was $23.0 \mathrm{mmol} \mathrm{m}^{-2}(\mathrm{SD}=4.8 ; \mathrm{n}=6)$ (Table 3).

The PP pool represented 5 to $6 \%$ of TP in nearsurface waters (Fig. 3c). Concentrations at 0 to $100 \mathrm{~m}$ ranged from 10 to $31 \mathrm{nM}$, with maximum values in the surface layers (Fig. 3c). Values were between 6 and $9 \mathrm{nM}$ at $120 \mathrm{~m}$ over most of the year. There was a small increase in surface concentrations in spring and at the beginning of fall, with values ca. 25 to $30 \mathrm{nM}$ (Fig. 3c) and also in the mean concentration of the mixed layer (Table 2). There was no major variation of total biomass throughout the year (Table 3), with an annual mean depth integrated particulate phosphate of $1.7 \mathrm{mmol} \mathrm{m}^{-2}(\mathrm{SD}=0.3 ; \mathrm{n}=6)$.

\section{Turnover times of orthophosphate}

Turnover times of orthophosphate are presented in Fig. 4: the $\log _{10}$ presentation enables the documentation of a large range in turnover values obtained throughout the water column and the year. Surface turnover values ranged from ca. $4 \mathrm{~h}$ at the beginning of fall to ca. $420 \mathrm{~h}$ in winter. Turnover times increased with depth, particularly from the phosphacline, and reached more than $1000 \mathrm{~h}$ at $120 \mathrm{~m}$. Seasonal variability of turnover times was stronger in the first $60 \mathrm{~m}$ of the water column. Values at 100 and $120 \mathrm{~m}$ were less accurate than others because of the low significance of measurements, due to the low ratio of incubation 
Table 2. Mean values of soluble reactive phosphate (SRP), particulate phosphate (PP), soluble non-reactive phosphate (SNP), turnover times of phosphate, and primary and bacterial productions in the mixed layer, for each cruise and season at Chenal des Loyauté station. Mean values for primary and bacterial productions are obtained by dividing mixed layer integrated inventories by the mixedlayer depth. $\mathrm{n}$ is the number of sampled depths in the mixed layer from which averages were calculated. Numbers in parentheses are SDs of the means. -: no data available

\begin{tabular}{|c|c|c|c|c|c|c|}
\hline & \multirow{2}{*}{$\begin{array}{c}\text { Spring } \\
\text { Oct } 2001 \\
(\mathrm{n}=3)\end{array}$} & \multicolumn{2}{|c|}{ Summer -} & \multicolumn{2}{|c|}{$\longrightarrow$ Fall $\longrightarrow$} & \multirow{2}{*}{$\begin{array}{c}\text { Winter } \\
\text { Aug 2002 } \\
(\mathrm{n}=8)\end{array}$} \\
\hline & & $\begin{array}{c}\text { Dec } 2001 \\
(\mathrm{n}=6)\end{array}$ & $\begin{array}{c}\text { Jan } 2002 \\
(\mathrm{n}=4)\end{array}$ & $\begin{array}{c}\text { Apr } 2002 \\
(\mathrm{n}=2)\end{array}$ & $\begin{array}{c}\text { May } 2002 \\
(\mathrm{n}=4)\end{array}$ & \\
\hline $\begin{array}{l}\text { SRP } \\
(\mathrm{nM})\end{array}$ & $\begin{array}{c}62.9 \\
(12.8)\end{array}$ & $<30$ & $<30$ & $<30$ & $<30$ & $\begin{array}{c}43.6 \\
(10.7)\end{array}$ \\
\hline $\begin{array}{l}\mathrm{PP} \\
(\mathrm{nM})\end{array}$ & $\begin{array}{l}24.4 \\
(6.4)\end{array}$ & $\begin{array}{l}15.6 \\
(2.7)\end{array}$ & $\begin{array}{l}11.9 \\
(0.3)\end{array}$ & 19.7 & $\begin{array}{l}15.8 \\
(4.7)\end{array}$ & $\begin{array}{l}17.2 \\
(5.3)\end{array}$ \\
\hline $\begin{array}{l}\text { SNP } \\
(\mathrm{nM})\end{array}$ & $\begin{array}{l}247.9 \\
(23.0)\end{array}$ & $\begin{array}{l}277.0 \\
(30.4)\end{array}$ & $\begin{array}{l}211.0 \\
(15.6)\end{array}$ & 248.9 & $\begin{array}{c}225.7 \\
(6.7)\end{array}$ & $\begin{array}{l}281.0 \\
(15.1)\end{array}$ \\
\hline $\begin{array}{l}\text { Turnover } \\
\text { time (h) }\end{array}$ & $\begin{array}{l}123.6 \\
(28.0)\end{array}$ & $\begin{array}{c}9.6 \\
(1.2)\end{array}$ & $\begin{array}{l}14.0 \\
(4.6)\end{array}$ & 4.3 & $\begin{array}{c}43.9 \\
(11.7)\end{array}$ & $\begin{array}{c}467.6 \\
(141.7)\end{array}$ \\
\hline $\begin{array}{l}\text { Primary } \\
\text { production } \\
\left(\mathrm{mgC} \mathrm{m}^{-3} \mathrm{~d}^{-1}\right)\end{array}$ & 4.86 & 3.18 & 2.63 & 3.27 & 3.64 & 5.68 \\
\hline $\begin{array}{l}\text { Bacterial } \\
\text { production } \\
\left(\mathrm{mgC} \mathrm{m}^{-3} \mathrm{~d}^{-1}\right)\end{array}$ & - & - & - & 0.60 & 0.19 & 0.27 \\
\hline
\end{tabular}

time:turnover time. Only the order of magnitude can be taken into account at these depths. The mean orthophosphate turnover time in the mixed layer showed a strong seasonal variability (Table 2), ranging from $4.3 \mathrm{~h}(\mathrm{n}=2)$ at the beginning of fall to $467.6 \mathrm{~h}$ (SD $=141.7 ; \mathrm{n}=8$ ) in winter.

\section{Indirectly estimated orthophosphate concentration}

$\left[\mathrm{PO}_{4}\right]$ were ca. $25 \mathrm{nM}$ in surface waters in spring (Fig. 5), when turnover times of orthophosphate were around $120 \mathrm{~h}$, and decreased to $1 \mathrm{nM}$ in surface waters in summer when turnover was around $10 \mathrm{~h}$. They decreased again in April to ca. $0.5 \mathrm{nM}$, when turnover times of orthophosphate were at a minimum (ca. 4 h). Then, they increased to 7 to $8 \mathrm{nM}$ in May, when turnovers were ca. $1.5 \mathrm{~d}$, and reached $90 \mathrm{nM}$ in winter, when turnover times of orthophosphate were ca. 2.5 wk. A strong seasonal variation of $\left[\mathrm{PO}_{4}\right]$ in surface waters was noticed. $\left[\mathrm{PO}_{4}\right]$ in spring and summer were calculated without considering bacterial production, as it was not measured. Values were then underestimated. An estimation was provided by considering a calculated annual average of bacterial production for the missing values. This gives an underestimation ranging from 8 to $33 \%$. This maximum percentage corresponded to an estimation of $0.8 \mathrm{nM}$ instead of $1.1 \mathrm{nM}$ in the surface-water sample in January. $\left[\mathrm{PO}_{4}\right]$ at depths $>60 \mathrm{~m}$ were not calculated because of the high uncertainties in turnover times and primary production measurements at these depths.
Table 3. Depth-integrated inventories (0 to $100 \mathrm{~m}$ ) of soluble reactive phosphate (SRP), particulate phosphate (PP), soluble non-reactive phosphate (SNP) and primary production. Annual averages and SDs were calculated for each cruise and season, with $\mathrm{n}=8$ to 10 depths. Depth-integrated inventories of bacterial production were calculated at 0 to $80 \mathrm{~m}$, with $\mathrm{n}=5$ depths

\begin{tabular}{|c|c|c|c|c|c|c|c|}
\hline & \multirow{2}{*}{$\begin{array}{c}\text { Spring } \\
\text { Oct } \\
2001\end{array}$} & \multicolumn{2}{|c|}{ Summer } & \multicolumn{2}{|c|}{$\longrightarrow$ Fall -} & \multirow{2}{*}{$\begin{array}{c}\text { Winter } \\
\text { Aug } \\
2002\end{array}$} & \multirow{2}{*}{$\begin{array}{l}\text { Annual } \\
\text { average }\end{array}$} \\
\hline & & $\begin{array}{c}\text { Dec } \\
2001\end{array}$ & $\begin{array}{c}\text { Jan } \\
2002\end{array}$ & $\begin{array}{c}\text { Apr } \\
2002\end{array}$ & $\begin{array}{l}\text { May } \\
2002\end{array}$ & & \\
\hline $\begin{array}{l}\text { SRP } \\
\left(\mathrm{mmol} \mathrm{m}^{-2}\right)\end{array}$ & 14.5 & 4.90 & 5.16 & 4.27 & 7.27 & 4.79 & $\begin{array}{c}6.81 \\
(3.89)\end{array}$ \\
\hline $\begin{array}{l}\mathrm{PP} \\
\left(\mathrm{mmol} \mathrm{m}^{-2}\right)\end{array}$ & 2.31 & 1.57 & 1.47 & 1.65 & 1.39 & 1.63 & $\begin{array}{c}1.67 \\
(0.33)\end{array}$ \\
\hline $\begin{array}{l}\text { SNP } \\
\left(\mathrm{mmol} \mathrm{m}^{-2}\right)\end{array}$ & 22.0 & 21.2 & 16.6 & 25.5 & 22.1 & 30.9 & $\begin{array}{l}23.0 \\
(4.8)\end{array}$ \\
\hline $\begin{array}{l}\text { Primary } \\
\text { production } \\
\left(\mathrm{mgC} \mathrm{m}^{-2} \mathrm{~d}^{-1}\right)\end{array}$ & 463.5 & 313.6 & 300.8 & 246.6 & 210.1 & 442.5 & $\begin{array}{c}329.5 \\
(102.9)\end{array}$ \\
\hline $\begin{array}{l}\text { Bacterial } \\
\text { production } \\
\left(\mathrm{mgC} \mathrm{m}^{-2} \mathrm{~d}^{-1}\right)\end{array}$ & - & - & - & 32.4 & 10.9 & 22.2 & $\begin{array}{c}21.8 \\
(10.7)\end{array}$ \\
\hline
\end{tabular}

\section{Primary and bacterial productions}

Primary production values ranged from $0.02 \mathrm{mgC} \mathrm{m}^{-3} \mathrm{~h}^{-1}$ at $120 \mathrm{~m}$ in fall to $7.5 \mathrm{mgC} \mathrm{m}^{-3} \mathrm{~h}^{-1}$ at $30 \mathrm{~m}$ in winter. Surface values ranged from $1.7 \mathrm{mgC} \mathrm{m}^{-3}$ $\mathrm{h}^{-1}$ in summer to $6.6 \mathrm{mgC} \mathrm{m}^{-3} \mathrm{~h}^{-1}$ in winter. Depth-integrated primary production of the (0 to $100 \mathrm{~m}$ ) water column (Table 3) showed a seasonal variability with higher values in spring (463.5 $\mathrm{mgC}$ $\mathrm{m}^{-2} \mathrm{~d}^{-1}$ ) and winter (442.5 $\mathrm{mgC} \mathrm{m}^{-2} \mathrm{~d}^{-1}$ ) and lower values in fall (246.6 to $210.1 \mathrm{mgC} \mathrm{m}^{-2} \mathrm{~d}^{-1}$ ). Bacterial production ranged from $0.004 \mathrm{mgC} \mathrm{m}^{-3} \mathrm{~h}^{-1}$ in May at $30 \mathrm{~m}$, to $0.023 \mathrm{mgC} \mathrm{m}^{-3} \mathrm{~h}^{-1}$ in April near the sea surface. The annual depth-integrated bacterial production average $(0$ to $80 \mathrm{~m})$ was $21.8(\mathrm{SD}=10.7$, $\mathrm{n}=3$ ) $\mathrm{mgC} \mathrm{m}^{-2} \mathrm{~d}^{-1}$ (Table 3). 


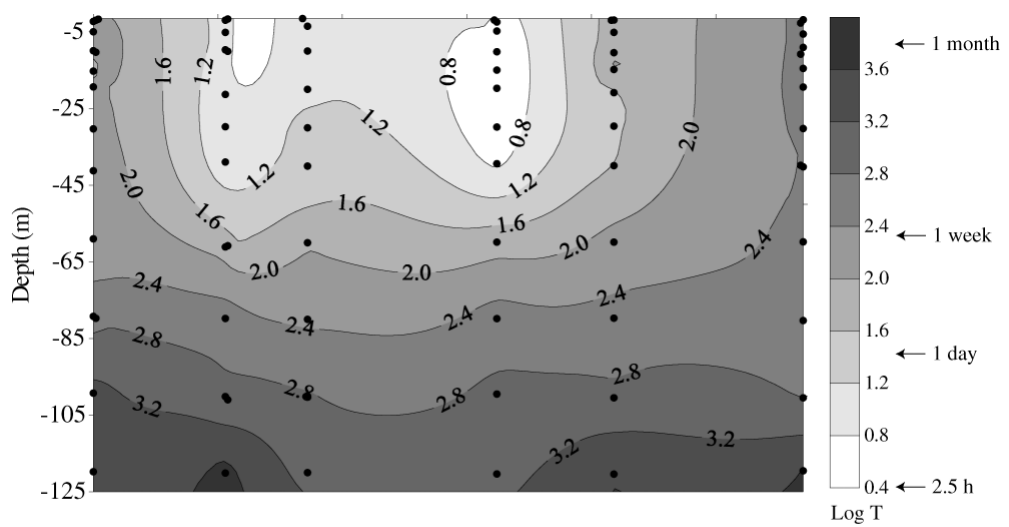

Oct-01 Dec-01 Jan-02 Apr-02 May-02 Aug-02 Spring Summer Fall Winter

Fig. 4. $\log _{10}$ of phosphate turnover times in the 0 to $100 \mathrm{~m}$ water column at Chenal des Loyauté station, from October 2001 to August 2002

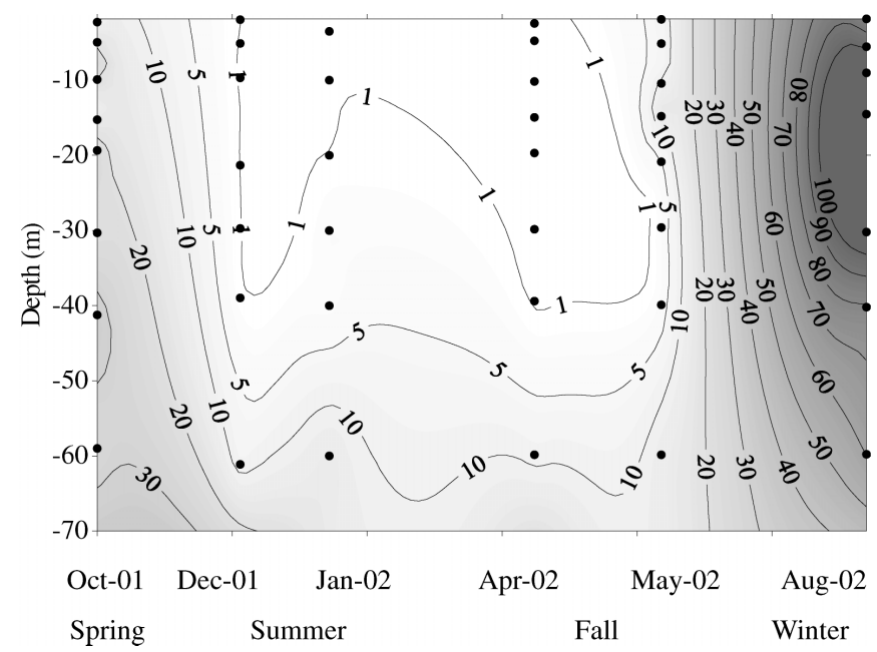

Fig. 5. Indirectly estimated orthophosphate concentration (nM) in the 0 to $60 \mathrm{~m}$ water column at Chenal des Loyauté station, from October 2001 to August 2002

\section{DISCUSSION}

\section{Phosphate availability at Chenal des Loyauté station}

$$
\text { P pools (SRP, SNP) }
$$

Orthophosphate concentration is the first indicator of phosphate availability. Winter and spring mean SRP concentrations in the mixed layer were higher than summer and fall ones, indicating a lower availability during these latter seasons. Because SRP measurements are close or below the detection limit of the method (30 nM) throughout the year, this parameter should be taken into account with precaution. Indeed, the SRP pool measured using the standard Murphy \& Riley (1962) procedure is not necessarily equivalent to the concentration of orthophosphate, which is directly available for the plankton. It may also include dissolved organic phosphate compounds hydrolyzed under the acidic reaction conditions (Karl \& Björkman 2002). Additionally, arsenate reacts with the Murphy \& Riley reagents and forms a blue-coloured complex of an equivalent molar absorptivity to the reduced phospho-molybdenum complex (Johnson et al. 1971). According to Middelburg et al. (1988), surface arsenate concentrations were similar in the Atlantic Ocean and Pacific Ocean and ranged from 14 to $18 \mathrm{nM}$. Results were not corrected from this interference, therefore the low SRP values obtained were slightly overestimated. As a consequence of the low accuracy of the method, in comparison with the low concentration in oligotrophic waters, estimating the SRP pool was not sufficient to characterize phosphate availability in these waters.

The phosphomolybdate technique is by far the most utilized method to determine the SRP pool (BenitezNelson 2000). A method for lowering the detection limit and minimizing interferences is through MAGIC (MAGnesium Induced Coprecipitation) preconcentration (Karl \& Tien 1992). According to Benitez-Nelson (2000), P concentrations can be determined using the MAGIC method to less than $5 \mathrm{nM}$ with a precision of \pm $1 \mathrm{nM}$. As the accuracy of orthophosphate determination using the MAGIC procedure during the DIAPALIS cruises was not better than using the classical method, the results were not presented. The low accuracy of the MAGIC results was due to the interference of suspended matter. According to Karl \& Tien (1992), if particulate phosphate (PP) is $\leq 10 \%$ of the total dissolved phosphate concentration, filtration is not necessary and is even undesirable because of potential contamination. Even if PP never exceeded $10 \%$ of the total dissolved phosphate concentration, laboratory assays conducted after the cruises showed that suspended matter interfere and that a prefiltration step is obligatory to lower the detection limit even in oligotrophic habitats. From SRP data, we showed that there are 2 distinct periods throughout the $1 \mathrm{yr}$ study period: one with detectable SRP and one with undetectable SRP. This is major information on nutrient availability in this unknown area.

Orthophosphate is generally the preferred substrate for microorganisms, but selected dissolved organic $\mathrm{P}$ compounds from the SNP pool may be available (Karl \& Björkman 2002, Mulholland et al. 2002, Björkman \& Karl 2003). Dissolved organic phosphate utilization 
depends on the SRP pool concentrations and on the expression of specific enzymes, i.e. alkaline phosphatase. As SRP stocks decrease, selection pressures for DOP utilization will increase (Karl et al. 2001a). Consequently, we should have observed a decrease in SNP pools during periods of low SRP pools. Actually, mean SNP pools were quite constant throughout the year, and we even observed a relatively high value in fall when the SRP pool was minimum (Table 3). As the SNP pool seems to have never been drastically used throughout the year, either we did not encounter any dramatic P depletion, or this pool is mainly composed of refractory organic material, i.e. dissolved organic $\mathrm{P}$ compounds unavailable for living organisms in this habitat.

\section{Turnover times of orthophosphate}

The study of turnover times of orthophosphate can provide an important insight into nutrient availability, particularly in oligotrophic surface waters. At the Chenal des Loyauté station, turnover times of orthophosphate varied between 0.17 and $19 \mathrm{~d}$ in the mixed layer, with an unexpected strong seasonal variation. Orthophosphate recycling was rapid in summer and fall, with turnover times ranging from 4 to $10 \mathrm{~h}$ in surface waters. Such short turnover times of orthophosphate suggest that $\mathrm{P}$ was in short supply during these warm periods. Suttle et al. (1990) suggested that turnover times of orthophosphate of 2 to $5 \mathrm{~h}$ was indicative of a P deficiency in the Sargasso Sea. Zohary \& Robarts (1998) proposed that values up to $7 \mathrm{~h}$ indicate $\mathrm{P}$ deficiency in the eastern Mediterranean Sea. Using this cut-off, it can be assumed that there is $\mathrm{P}$ deficiency in surface waters at the Chenal des Loyauté station, especially in fall, when turnover times of orthophosphate were 4 to $5 \mathrm{~h}$. Long turnover times of orthophosphate were measured in spring (ca. $120 \mathrm{~h}$ ) and in winter (2.5 wk). According to Zohary \& Robarts (1998), turnover times of orthophosphate greater than $100 \mathrm{~h}$ indicate $\mathrm{P}$ sufficiency: it means that without additional input other than recycling, orthophosphate concentration may sustain more than $4 \mathrm{~d}$ of production.

Because turnover times of orthophosphate in seawater is a function of in situ concentrations and fluxes of orthophosphate (uptake by bacterio- and phytoplankton), differences in turnover times between environments, in time and space, are most likely related to variations in both biological assimilation and $\mathrm{PO}_{4}$ concentrations. The long turnover times of $\mathrm{PO}_{4}$ are due to high $\mathrm{PO}_{4}$ concentrations and/or very low rates of biological assimilation, while the short turnover times result from low $\mathrm{PO}_{4}$ concentrations and/or moderate to rapid fluxes.
Seasonal variation of turnover times was principally concomitant to the seasonal variation of SRP concentration. However, SRP concentrations varied over a narrow range (ca. 2-fold), whereas turnover times of orthophosphate varied over a large range (ca. 100-fold). These variations may be explained by differences in planktonic uptake or by differences between [SRP] and $\left[\mathrm{PO}_{4}\right]$. Mean bacterial and primary carbon productions in the mixed layer varied from 0.19 to 0.60 and 2.6 to 5.7 $\mathrm{mgC} \mathrm{m}^{-3} \mathrm{~d}^{-1}$ over the study period (i.e. ca. 3 - and 2 -fold, respectively). Considering that carbon and phosphate cell requirements varied according to the same ratio, seasonal variations in biological uptake could not explain the seasonal variations in turnover times. Therefore, the 'real' orthophosphate concentration should be largely below what was measured as SRP to assess the 100-fold range of variations obtained from turnover time measurements.

The turnover times of orthophosphate in marine planktonic communities vary spatially within a wide range. In coastal regimes, SRP turnover times are typically rapid, ranging from $<1 \mathrm{~h}$ to just over $1 \mathrm{wk}$; in contrast, SRP turnover times in open ocean environments are generally longer, on the order of $1 \mathrm{wk}$ to several months (Benitez-Nelson 2000 and references therein). Short turnover times of orthophosphate were observed at Chenal des Loyauté during summer and fall, although this station is typically oceanic. Indeed, the analysis of densities $\left(\sigma_{t}\right)$ and the T-S diagram (Fig. 6a) showed that surface waters, with equatorial characteristics $\left(\sigma_{t}<23.92\right)$ as defined by Hénin et al. (1984), occurred from spring 2001 to winter 2002 in the upper water column. The same water mass was sampled throughout the year indicating mixing between this water and subtropical water coming from Polynesia $\left(35.5<\mathrm{S}<35.7 \mathrm{PSU}_{;} 22<\mathrm{T}<23^{\circ} \mathrm{C}\right)$. The lower salinities observed corresponded to a period of high precipitations. No influence from coastal waters was noted. Thus, the short turnover times of orthophosphate measured were not due to a coastal influence. Such short turnover times of orthophosphate $(<10 \mathrm{~h})$ associated with open ocean habitats have already been observed in the Sargasso Sea (Suttle et al. 1990, Cotner et al. 1997) and in the Mediterranean Sea (Moutin et al. 2002).

Our estimates of turnover times of orthophosphate are shorter than those reported in several previous studies in the North Pacific Ocean. No data of turnover times are available for the South Pacific Ocean. Perry \& Eppley (1981) measured relatively long turnover times of orthophosphate in the central North Pacific Ocean: $19 \mathrm{~d}$ in June, $31 \mathrm{~d}$ in December and $28 \mathrm{~d}$ in March, and concluded that there was no seasonal variation of turnover times in these euphotic waters. Sorokin (1985) reported turnover times of 40 to $100 \mathrm{~d}$ in 
the oligotrophic waters of the eastern tropical Pacific Ocean. Björkman et al. (2000) measured summer orthophosphate turnover times at the station ALOHA which varied from 2 to $40 \mathrm{~d}$, i.e. with a minimum far above what we observed $(0.17 \mathrm{~d})$. Therefore, phos-
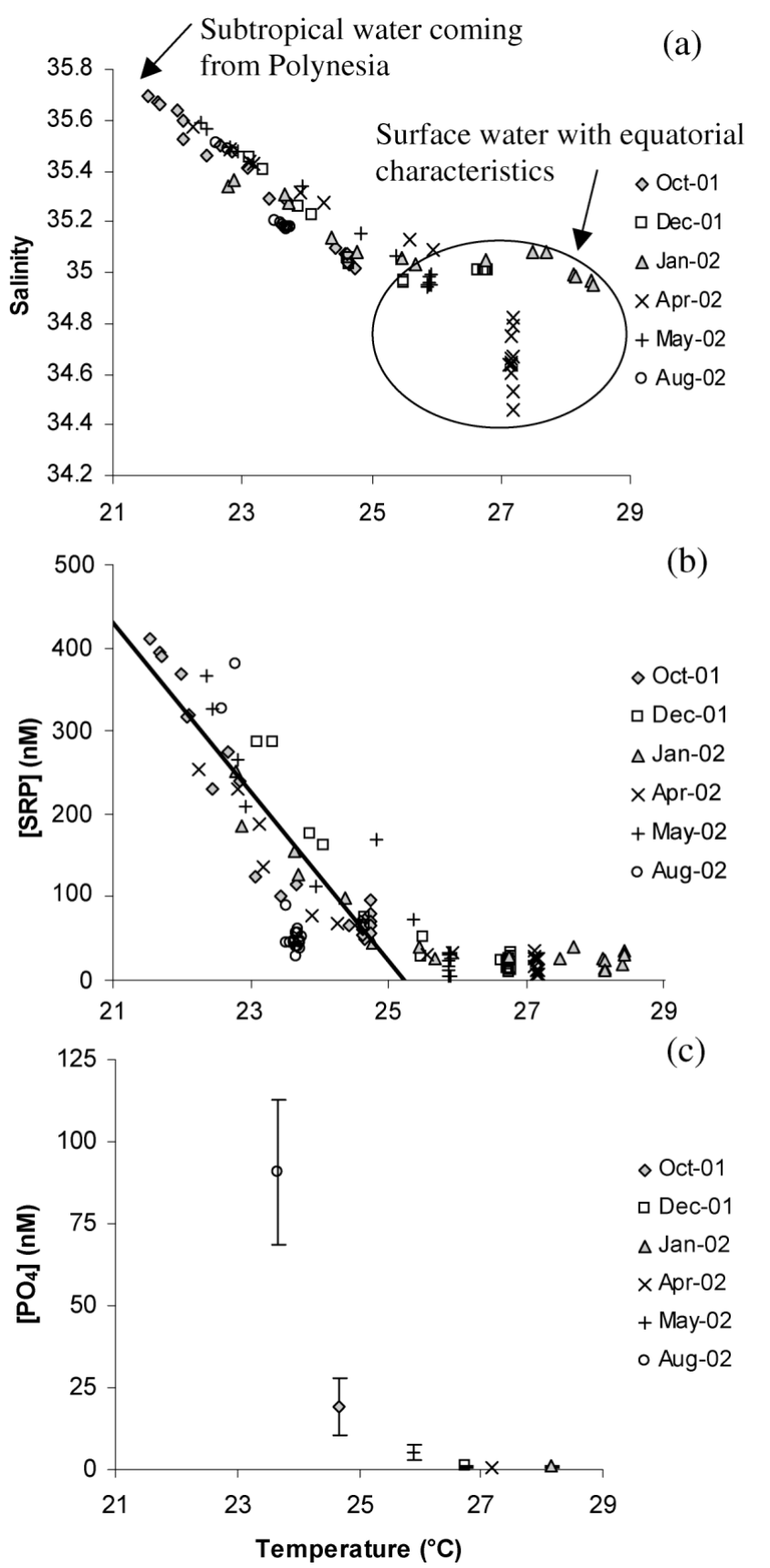

Fig. 6. (a) Salinity versus temperature (S-T diagram) data from 0 to $120 \mathrm{~m}$ water sampled during the 6 cruises. (b) Soluble reactive phosphate (SRP) concentration versus temperature of the (0 to $120 \mathrm{~m}$ ) waters. The linear regression is drawn for SRP >50 nM. (c) Mean indirectly estimated orthophosphate concentration vs temperature in the mixed layer phate availability, based on turnover time measurements, seems to be much lower at the Chenal des Loyauté station than in other areas which have been studied in the North Pacific open ocean.

Indirectly estimated orthophosphate concentration

Orthophosphate concentrations obtained from turnover times, bacterial and primary productions, varied from 90 to $0.5 \mathrm{nM}$ throughout the year in the upper photic zone. Apart from winter, $\left[\mathrm{PO}_{4}\right]$ was much lower than [SRP] measured with the standard method. The very low values calculated in fall were consistent with the $0.8 \mathrm{nM}$ obtained in Villefranche Bay, NW Mediterranean Sea, based also on turnover time and rate, but obtaining the rate from loss of radioactivity from the particulate fraction (Thingstad et al. 1996). They are also consistent with the 0.1 to $3 \mathrm{nM}$ range obtained from Gibraltar to the Ionian sea in the Mediterranean Sea using the method described in this study (Moutin et al. 2002).

Orthophosphate concentration at the climax station (near ALOHA) in summer 1997 was $14 \mathrm{nM}$, and turnover times was $2 \mathrm{~d}$ (Björkman et al. 2000). If $2 \mathrm{~d}$ turnover time corresponds to ca. $10 \mathrm{nM}$ of orthophosphate, then turnover times of several hours cannot correspond to concentrations of ca. $30 \mathrm{nM}$. Orthophosphate concentrations at the Chenal des Loyauté station should therefore be much lower than those measured with the standard SRP determination. Our lower turnover times of orthophosphate $<0.5 \mathrm{~d}$ may correspond to orthophosphate concentrations in the nanomolar range, as this was calculated using the indirect method.

Large uncertainties in $\left[\mathrm{PO}_{4}\right]$ may come from uncertainties in the $\mathrm{C}: \mathrm{P}$ ratios used in the calculation. Indeed, the C:P ratio for phytoplankton and bacterioplankton uptakes may vary generally from $75: 1$ to 150:1 and from 29:1 to $65: 1$, respectively, in the open ocean (Moutin et al. 2002 and references therein). Recently, Gundersen et al. (2002) gave a maximum value for bacterial C:P ratios of 142.9 in the Sargasso Sea. Calculation of $\left[\mathrm{PO}_{4}\right]$ was made using these minimum and maximum values for surface waters and did not give a large difference in indirectly estimated orthophosphate concentration $(0.8$ to $1.5 \mathrm{nM}$ in December, 0.6 to $1.2 \mathrm{nM}$ in January, 0.3 to $0.8 \mathrm{nM}$ in April, 5 to $10 \mathrm{nM}$ in May, 56 to $118 \mathrm{nM}$ in August). Therefore, the natural variability in the C:P uptake ratios did not affect the order of magnitude of the calculated concentrations. Taking into account this maximum range of the $\mathrm{C}: \mathrm{P}$ ratios, indirectly estimated orthophosphate concentrations varied from $0.3-0.8$ to 56-118 nM. 
Phosphate availability and temperature of water

There was a significant linear relationship between concentrations of SRP >50 nM and temperatures throughout the year (Fig. 6b). This was essentially attributable to physical processes, i.e. the mixing of deeper and colder subtropical water with high SRP concentrations and relatively warm equatorial surface water with low SRP concentrations. In surface waters where biological processes dominated, no evident relationship between SRP $<50$ nM and temperature occurred. However, when considering $\left[\mathrm{PO}_{4}\right]$ in the mixed layer, there was a decrease in concentration with an increase in temperature (Fig. 6c). A roughly exponential decrease from $91 \pm 22 \mathrm{nM}$ with temperatures of ca. $23.7^{\circ} \mathrm{C}$ in winter, to $0.9 \pm 0.1 \mathrm{nM}$ with temperatures of ca. $28.2^{\circ} \mathrm{C}$ in summer was observed. Biological processes in surface waters led to a decreasing availability of phosphate during the warmer periods, which could only be detected using a very sensitive orthophosphate determination.

Phosphate availability and primary production

The availability of phosphate in natural systems could significantly affect biological production (Lebo 1990), especially in areas where $\mathrm{N}_{2}$ fixation is a significant process. Integrated SRP values were higher in spring and winter, when higher integrated primary productions were measured (Table 3). Sorokin (1985) found a high positive correlation between uptake of orthophosphate and primary production in the eastern tropical Pacific Ocean from oligotrophic to eutrophic areas. Orthophosphate uptake could not be calculated at the Chenal des Loyauté station because SRP measurements were close to the analytical detection limit. Indeed, the lower SRP value measured by Sorokin (1985) was higher than the maximum value measured at the Chenal des Loyauté station.
Primary production and turnover times of orthophosphate in the mixed layer evolved over the year in a similar manner. Mean primary production in the mixed layer was high in spring $\left(4.86 \mathrm{mgC} \mathrm{m}^{-3} \mathrm{~d}^{-1}\right)$ and winter (5.68 $\mathrm{mgC} \mathrm{m}^{-3} \mathrm{~d}^{-1}$ ) when turnover times were above $100 \mathrm{~h}$. In summer and fall, when turnover times were $<50 \mathrm{~h}$, mean primary production was $3.03 \mathrm{mgC} \mathrm{m}^{-3} \mathrm{~d}^{-1}$. These 2 indicators of phosphate availability, SRP concentration and turnover times of orthophosphate varied, like primary production, throughout the year, which seems to indicate that phosphate may play a key role in controlling primary production in this area.

\section{Comparison with ALOHA station}

There is no comparable data set in the SW Pacific Ocean. For a more comprehensive understanding of phosphate dynamics in these open ocean habitats, data from this study have been contrasted with data sets at the ALOHA station in the eastern sector of the North Pacific Ocean Gyre (Table 4). SRP concentrations in the upper water column at the ALOHA station were also near the detection limit of traditional analytical techniques throughout the year. It ranged from $<10$ to ca. 100 nM (Karl et al. 2001b, Björkman \& Karl 2003). At ALOHA, the depths of the phosphacline averaged $115 \mathrm{~m}$ in the $9 \mathrm{yr}$ study, with a considerable month-tomonth and interannual variability from $<100$ to $>200 \mathrm{~m}$ (Karl et al. 2001b). At Chenal des Loyauté, it ranged from 42 to $97 \mathrm{~m}$. At the ALOHA station, [SNP] in the upper $100 \mathrm{~m}$ of the water column averaged 200 to 220 nM (Karl \& Björkman 2002), and the entire data set ranged from ca. 150 to $350 \mathrm{nM}$ (Karl et al. 2001b). This range was identical to what we observed at the Chenal des Loyauté station (Table 4). Mean concentrations of $\mathrm{PP}$ for the entire data set ranged from 4.8 to $35.2 \mathrm{nM}$ in the first $100 \mathrm{~m}$ at ALOHA (Hebel \& Karl 2001, Björkman \& Karl 2003). PP concentrations at the Chenal des

Table 4. Depth of the phosphacline, concentrations of soluble reactive phosphate (SRP), soluble non-reactive phosphate (SNP), particulate phosphate (PP) on 0 to $100 \mathrm{~m}$, turnover times of orthophosphate, and primary productions at Chenal des Loyauté and ALOHA stations

\begin{tabular}{|c|c|c|c|c|c|c|}
\hline & \multirow[b]{2}{*}{ Phosphacline (m) } & \multicolumn{3}{|c|}{$\longrightarrow$ P pool $(0-100 \mathrm{~m})$ in $\mathrm{nM}-$} & \multirow{2}{*}{$\begin{array}{l}\text { Turnover times of } \\
\text { orthophosphates } \\
\text { (d) }\end{array}$} & \multirow{2}{*}{$\begin{array}{c}\text { Primary } \\
\text { production } \\
\left(\mathrm{mgC} \mathrm{m}^{-2} \mathrm{~d}^{-1}\right)\end{array}$} \\
\hline & & SRP & SNP & PP & & \\
\hline $\begin{array}{l}\text { Chenal des } \\
\text { Loyauté }\end{array}$ & $42-97$ & $<30-368$ & $105-305$ & $10-31.7$ & $\begin{array}{c}0.17-19 \\
\text { (mixed layer, } 1 \text { yr study) }\end{array}$ & $\begin{array}{c}329.5 \\
(102.9 ; \mathrm{n}=6)\end{array}$ \\
\hline $\begin{array}{l}\text { ALOHA } \\
9 \text { yr study } \\
(1988-1997)\end{array}$ & $\begin{array}{c}\sim 115 \\
(<100->200) \\
(\text { Karl et al. 2001b) }\end{array}$ & $\begin{array}{c}10->100 \\
(\text { Karl et al. } \\
2001 b)\end{array}$ & $\begin{array}{c}150-350 \\
\text { (Karl et al. } \\
2001 b)\end{array}$ & $\begin{array}{c}4.8-35.2 \\
(\text { Hebel \& } \\
\text { Karl 2001) }\end{array}$ & $\begin{array}{c}2-40 \\
(5 \mathrm{~m} \text {, in summer) } \\
\text { (Björkman et al. 2000) }\end{array}$ & $\begin{array}{c}473 \\
(123 ; \mathrm{n}=74) \\
(\text { Karl et al. 2001a) }\end{array}$ \\
\hline $\begin{array}{l}1 \text { yr study } \\
(2000-2001)\end{array}$ & $>100$ & $7-84$ & $\begin{array}{c}170-280 \\
\text { (Björkman \& Karl }\end{array}$ & $8-25$ & & \\
\hline
\end{tabular}


Loyauté station were similar and ranged from 6.0 to $31.7 \mathrm{nM}$ in the first $100 \mathrm{~m}$ with an annual average concentration of $17.1 \mathrm{nM}$. The comparison of the SRP, SNP and PP pools at Chenal des Loyauté and ALOHA stations indicated a similar pattern. Karl et al. (2001b) noted that SRP concentrations at the ALOHA station were minimum in fall. There was no evidence for large seasonal variations in the SNP pool (Karl et al. 2001b), and PP concentration at ALOHA exhibited a small seasonal variation with a distinct spring maximum (Hebel \& Karl 2001). These trends, and absences of trends, were also observed at the Chenal des Loyauté station. Although P pools at the ALOHA and Chenal des Loyauté stations were similar and presented roughly the same seasonal evolution, turnover times of orthophosphate indicated a major difference. Indeed, summer turnover times were significantly lower at the Chenal des Loyauté station (Tables $2 \& 4$ ) indicating a larger $\mathrm{P}$ deficiency at Chenal des Loyauté than at the ALOHA station in the upper waters.

This higher P deficit at the surface, although depths of phosphacline were lower, could have arisen from selective removal processes more efficient at Chenal. The higher $\mathrm{P}$ depletion may originate from Trichodesmium blooms (and associated organic matter export) frequently observed in that region (Dupouy et al. 2000).

In summary, a strong seasonal variation in phosphate availability was pointed out in this region of the SW Pacific Ocean. Two distinct periods occurred: the winter and spring period, corresponding to detectable SRP, high turnover times of orthophosphate and $\left[\mathrm{PO}_{4}\right]$ $>20 \mathrm{nM}$ and the summer and fall period with undetectable SRP, short turnover times and $\left[\mathrm{PO}_{4}\right]<10 \mathrm{nM}$. Such low availability of orthophosphate has never been observed in the Pacific Ocean. Nevertheless, turnover times of ca. $4 \mathrm{~h}$, close to what we measured, were reported in the Atlantic Ocean at the BATS station in the Sargasso Sea (Cotner et al. 1997, Ammerman et al. 2003). This higher P deficiency at BATS might result from the control of nitrogen fixation by iron supply (Wu et al. 2000). Indeed, areal rates of eolian iron input into the surface Sargasso Sea are 2- to 10-fold higher than in Pacific waters (Duce \& Tindale 1991, Duce et al. 1991, Prospero et al. 1996). The Equatorial Undercurrent, which originates near Papua New Guinea, close to New Caledonia, is known to be a source of iron in the South Pacific Ocean (Wells et al. 1999). Moreover, iron concentrations measured during Diapalis cruises (M. Rodier unpubl. data) were higher than concentrations reported in the sub-tropical North Pacific (Landing \& Bruland 1987). As hypothesized by Wu et al. (2000) in the Sargasso Sea, the higher input of iron could drive in such a depletion of $\mathrm{P}$ in the SW Pacific Ocean near New Caledonia.
Studying phosphate availability for planktonic production is the first step in understanding the possible phosphate control of the nitrogen and carbon cycles in this area. The future objectives will be to link the large variation in phosphate availability presented here with the occurrence of diazotroph blooms and $\mathrm{N}_{2}$ fixation rates.

Acknowledgements. The authors would like to thank J. Y. Panche and D. Varillon for CTD data. In addition, the captain and crew of RV 'Alis' are thanked for outstanding shipboard support operations at sea. This work was supported by IRD, INSUE and by the French program PROOF (Processus biogéochimiques dans l'océan et flux).

\section{LITERATURE CITED}

Ammerman JW, Hood RR, Case DA, Cotner JB (2003) Phosphorus deficiency in the Atlantic: an emerging paradigm in oceanography. EOS 64(18):165-170

Benitez-Nelson CR (2000) The biogeochemical cycling of phosphorus in marine systems. Earth-Sci Rev 51:109-135

Bishop JKB (1989) Regional extremes in particulate matter composition and flux: effects on the chemistry of the ocean interior. In: Berger WH, Smetacek VS, Wefer G (eds) Report of the Dahlen workshop on productivity of the ocean: present and past. John Wiley \& Sons, Chichester, p $117-137$

Björkman KM, Karl DM (2003) Bioavailability of dissolved organic phosphorus in the euphotic zone at the Station ALOHA, North Pacific Subtropical Gyre. Limnol Oceanogr 48(3):1049-1057

Björkman K, Thomson-Bulldis AL, Karl DM (2000) Phosphorus dynamics in the North Pacific subtropical gyre. Aquat Microb Ecol 22:185-198

Capone DG (2001) Marine nitrogen fixation: what's the fuss? Curr Opin Microbiol 4:341-348

Carpenter EJ, Romans K (1991) Major role of the Cyanobacterium Trichodesmium in nutrient cycling in the North Atlantic Ocean. Science 254:1356-1358

Codispoti LA (1989) Phosphorus vs nitrogen limitation of new and export production. In: Berger WH, Smetacek VS, Wefer G (eds) Productivity of the ocean: present and past. John Wiley, New York, p 377-394

Cotner JB, Ammerman JW, Peele ER, Bentzen E (1997) Phosphorus limited bacterioplankton growth in the Sargasso Sea. Aquat Microb Ecol 13:141-149

Delcroix T, Lenormand O (1997) ENSO signals in the vicinity of New Caledonia, South Western Pacific. Oceanol Acta 20(3):481-491

Duce RA, Tindale, NW (1991) Atmospheric transport of iron and its deposition in the ocean. Limnol Oceanogr 36:1715-1726

Duce RA, Liss PS, Merill JT, Atlas EL and 16 others (1991) The atmospheric input of trace species to the world ocean. Global Biogeochem Cycles 5(3):193-259

Dupouy C (1992) Discoloured waters in the melanesian archipelago (New Caledonia and Vanuatu): the value of the Nimbus-7 coastal zone colour scanner observations. In: Carpenter EJ, Capone DG, Rueter J (eds) Marine pelagic cyanobacteria: Trichodesmium and other Diazotrophs. Kluwer Academic Publishers, Boston, p 177-191

Dupouy C, Neveux J, Subramaniam A, Mulholland MR, Montoya JP, Campbell L, Carpenter EJ, Capone DG (2000) Satellite captures Trichodesmium blooms in the southwestern tropical Pacific. EOS 81(2):13-16 
Eppley RW, Renger EH, Venrick EL, Mullin MM (1973) A study of plankton dynamics and nutrient cycling in the central gyre of the North Pacific Ocean. Limnol Oceanogr 18:534-551

Falkowski PG (1997) Evolution of the nitrogen cycle and its influence on the biological sequestration of $\mathrm{CO}_{2}$ in the ocean. Nature 387:272-275

Fu FX, Bell PRF (2003) Effect of salinity on growth, pigmentation, N2 fixation and alkaline phosphatase activity of cultured Trichodesmium sp. Mar Ecol Prog Ser 257:69-76

Fukuda R, Ogawa H, Nagata T, Koike I (1998) Direct determination of carbon and nitrogen contents of natural assemblages in marine environnements. Appl Environ Microbiol 64:3352-3358

Fuhrman JA, Azam F (1982) Thymidine incorporation as a measure of heterotrophic bacterioplankton production in marine surface waters: evaluation and field results. Mar Biol 66(2):109-120

Gundersen K, Heldal M, Norland S, Purdie DA, Knap AH (2002) Elemental C, N, and P cell content of individual bacteria collected at the Bermuda Atlantic Time-series Study (BATS) site. Limnol Oceanogr 47(5):1525-1530

Hebel DV, Karl DM (2001) Seasonal, interannual and decadal variations in particulate matter concentrations and composition in the subtropical North Pacific Ocean. Deep-Sea Res II 48:1669-1695

Hénin C, Guillerm JM, Chabert L (1984) Circulation superficielle autour de la Nouvelle Calédonie. Océanogr Trop 19(2):113-126

Herbland A (1984) Phosphate uptake in the euphotic layer of the Equatorial Atlantic Ocean: methodological observations and ecological significance. Océanogr Trop 19:24-40

Johnson DL (1971) Simultaneous determination of arsenate and phosphate in natural waters. Nature 5:411-414

Karl DM, Björkman KM (2002) Dynamics of DOP. In: Hansell DA, Carlson CA (eds) Biogeochemistry of marine dissolved organic matter. Elsevier Science, San Diego, p 249-366

Karl DM, Tien G (1992) MAGIC: A sensitive and precise method for measuring dissolved phosphorus in aquatic environment. Limnol Oceanogr 37(1):105-116

Karl DM, Letelier L, Tupas L, Christian J, Hebel D (1997) The role of nitrogen fixation in biogeochemical cycling in the subtropical North Pacific Ocean. Nature 388:533-538

Karl DM, RR Bidigare, RM Letelier (2001a) Long-term changes in plankton community structure and productivity in the North Pacific Subtropical Gyre: the domain shift hypothesis. Deep-Sea Res II 48:1449-1470

Karl DM, Björkman KM, Dore JE, Fujieki L, Hebel DV, Houlihan T, Letelier RM, Tupas LM (2001b) Ecological nitrogen-to-phosphorus stoichiometry at station ALOHA. Deep-Sea Res II 48(9):1529-1566

Karl DM, Michaels A, Bergman B, Capone D and 6 others (2002) Dinitrogen fixation in the world's oceans. Biogeochemistry 57/58:47-98

Kustka A, Carpenter EJ, Sañudo-Wilhelmy SA (2002) Iron and marine nitrogen fixation: progress and future directions. Res Microbiol 153:255-262

Landing WM, Bruland KW (1987) The contrasting biogeochemistry of iron and manganese in the Pacific Ocean. Geochim Cosmochim Acta 51:29-43

Lebo ME (1990) Phosphate uptake along a coastal plain estuary. Limnol Oceanogr 35(6):1279-1289

Moutin T, Raimbault P (2002) Primary production, carbon export and nutrients availability in western and eastern Mediterranean Sea in early summer 1996 (MINOS cruise). J Mar Syst 33/34:273-288
Moutin T, Raimbault P, Poggiale JC (1999) Production primaire dans les eaux de surface de la Méditerranée occidentale: calcul de la production journalière. CR Acad Sci Paris Ser Gen Sci Vie 322:651-659

Moutin T, Thingstad TF, VanWambeke F, Marie D, Slawyk G, Raimbault P, Claustre H (2002) Does competition for nanomolar phosphate supply explain the predominace of the cyanobacterium Synechococcus? Limnol Oceanogr 47(5):1562-1567

Mulholland MR, Floge S, Carpenter EJ, Capone DG (2002) Phosphorus dynamics in cultures and natural populations of Trichodesmium spp. Mar Ecol Prog Ser 239:45-55

Murphy J, Riley JP (1962) A modified single solution method for the determination of phosphate in natural waters. Anal Chim Acta 27:31-36

Perry MJ (1976) Phosphate utilization by an oceanic diatom in phosphorus limited chemostat culture and in the oligotrophic waters of the central North Pacific Ocean. Limnol Oceanogr 21:88-107

Perry MJ, Eppley RW (1981) Phosphate uptake by phytoplankton in the central North Pacific Ocean. Deep-Sea Res 28:39-49

Prospero JM, Barrett K, Church T, Dentener F and 5 others (1996) Atmospheric deposition of nutrients to the North Atlantic Basin. Biogeochemistry 35:27-73

Pujo-Pay M, Raimbault P (1994) Improvement of the wetoxidation procedure for simultaneous determination of particulate organic nitrogen and phosphorus collected on filters. Mar Ecol Prog Ser 105:203-207

Radenac MH, Rodier M (1996) Nitrate and chlorophyll distributions in relation to thermohaline and current structures in the western tropical Pacific during 1985-1989. DeepSea Res II 43(4-6):725-752

Sañudo-Wilhelmy SA, Kustka AB, Gobler CJ, Hutchins DA and 6 others (2001) Phosphorus limitation of nitrogen fixation by Trichodesmium in the central Atlantic Ocean. Nature 411:66-69

Sorokin YI (1985) Phosphorus metabolism in planktonic communities on the eastern tropical Pacific Ocean. Mar Ecol Prog Ser 27:87-97

Suttle CA, Fuhrman JA, Capone DG (1990) Rapid ammonium cycling and concentration-dependent partitioning of ammonium and phosphate: implications for carbon transfer in planktonic communities. Limnol Oceanogr 35:424-433

Thingstad TF, Skjoldal EF, Bohne RA (1993) Phosphorus cycling and algal-bacterial competition in Sandsfjord, western Norway. Mar Ecol Prog Ser 99:239-259

Thingstad TF, Dolan JR, Fuhrman JA (1996) Loss rate of an oligotrophic bacterial assemblage as measured by ${ }^{3} \mathrm{H}-$ thymidine and ${ }^{32} \mathrm{PO}_{4}$ : good agreement and near-balance with production. Aquat Microb Ecol 10:29-36

Tyrell T (1999) The relative influences of nitrogen and phosphorus on oceanic primary production. Nature 400: $525-531$

Valderrama JC (1981) The simultaneous analysis of total nitrogen and total phosphorus in natural water. Mar Chem 10:102-122

Wells ML, Vallis GK, Silver EA (1999) Tectonic processes in Papua New Guinea and past productivity in the eastern equatorial Pacific Ocean. Nature 398:601-604

Wu J, Sunda W, Boyle EA, Karl DM (2000) Phosphate depletion in the western North Atlantic Ocean. Science 289: 759-762

Zohary T, Robarts RD (1998) Experimental study of microbial $\mathrm{P}$ limitation in the eastern Mediterranean. Limnol Oceanogr 43(3):387-395

Submitted: October 10, 2003; Accepted: December 2, 2003 Proofs received from author(s): March 2, 2004 